\title{
Dialog obywatelski online a jakość polityki publicznej. Modele komunikacji administracji publicznej z obywatelami w mediach społecznościowych na przykładzie komunikacji prowadzonej na Twitterze przez wybrane polskie miasta
}

\begin{abstract}
Streszczenie
Dialog obywatelski wpływa na jakość prowadzonej polityki publicznej, w formie online umożliwia bezpośrednie wpływanie interesariuszy na proces jej formułowania i implementacji. Stanowi również nową jakość w procesie ewaluacji polityki publicznej. Dialog obywatelski rozumiany jest najczęściej jako proces komunikacji pomiędzy władzą państwową a organizacjami pozarządowymi, autor artykułu wskazuje jednak, że możliwe jest prowadzenie dialogu obywatelskiego w sposób bezpośredni z obywatelami za pomocą mediów społecznościowych. Przedstawia wyniki badań, których celem była weryfikacja sposobu korzystania przez władzę z mediów społecznościowych w celu nawiązania dialogu z obywatelami. Badanie polegało na pomiarach i analizie komunikacji prowadzonej przez wybrane polskie miasta wojewódzkie w serwisie społecznościowym Twitter. Autor wskazuje na charakterystyczne style komunikacji, które można interpretować z perspektywy dialogu obywatelskiego.
\end{abstract}

Słowa kluczowe: dialog obywatelski, polityka publiczna media społecznościowe, Twitter DOI: $10.33119 / \mathrm{KSzPP} / 2019.2 .4$

\footnotetext{
1 Instytut Nauk Politycznych na Wydziale Nauk Politycznych i Studiów Międzynarodowych Uniwersytetu Warszawskiego, p.o. dyrektora Ośrodka Analiz Politologicznych UW
} 


\title{
Civil dialogue online and the quality of public policy. Models of social media communication by public administration on the example of Twitter activities of selected Polish cities
}

\begin{abstract}
Civil dialogue has an impact on the quality of public policy, in the online form it allows direct influence of stakeholders on the process of formulation and its implementation. It is also a new quality in the process of evaluating public policy. Civil dialogue is usually understood as a process of communication between the state authority and non-governmental organizations, but the author of the article indicates that it is possible to conduct civil dialogue in a direct way with citizens through social media. He presents the results of research aimed at verifying the use of social media by the authorities in order to establish a dialogue with citizens. The research consisted in measuring and analyzing communication conducted by selected Polish voivodeship cities on the Twitter social network. The author points out the characteristic styles of communication that can be interpreted from the perspective of civil dialogue.
\end{abstract}

Keywords: civil dialogue, social media, Twitter

\section{Dialog obywatelski a media społecznościowe}

Dialog obywatelski rozumiany jest najczęściej jako proces komunikacji pomiędzy władzą państwową a organizacjami pozarządowymi, które będąc formami prawnymi zrzeszającymi obywateli, pozwalają na przekazywanie stanowisk obywateli w sposób zorganizowany (Rymsza, 2007; Bogacz-Wojtanowska, 2017; Cisek-Lachowicz, Kichewko, 2018). Jednocześnie, jak pisze M. Rymsza (2009), „istotą dialogu obywatelskiego jako rozwiązania instytucjonalnego jest uspołecznienie procesów podejmowania decyzji publicznych przez umożliwienie obywatelom (a zwłaszcza sformalizowanym strukturom reprezentującym obywateli, w tym organizacjom pozarządowym) systematycznego wpływu na proces stanowienia prawa i przygotowywania dokumentów państwowych dotyczących bezpośrednio tychże obywateli”. Uprawniony jest zatem pogląd, że instytucjonalizacja dialogu w formie relacji pomiędzy instytucjami administracji publicznej a organizacjami społecznymi reprezentującymi obywateli stanowi formę, a nie kwintesencję dialogu obywatelskiego. Tym samym otwiera to drogę do analizowania innych - $\mathrm{w}$ tym niezinstytucjonalizowanych - form dialogu obywatelskiego, np. tych prowadzonych w mediach społecznościowych, 
w których komunikują się obecnie zarówno instytucje administracji publicznej, partie polityczne, politycy, organizacje pozarządowe, jak i „niezorganizowani”, indywidualni obywatele. Możliwość prowadzenia dialogu obywatelskiego z indywidualnymi obywatelami nie czyni w żaden sposób zbędnymi organizacji trzeciego sektora - nie wszyscy obywatele korzystają z narzędzi komunikacji elektronicznej, nie wszyscy mają też możliwość bezpośredniego angażowania się w dialog i należy uznać, że organizacje społeczne nadal będą odgrywały kluczową rolę w procesach dialogu obywatelskiego. Jednocześnie włączenie nowych kanałów komunikacyjnych i ułatwienie komunikacji niezorganizowanym obywatelom ma charakter potencjalnie wzmacniający dialog obywatelski, podobnie jak takie mechanizmy, jak głosowania nad budżetem partycypacyjnym, w których to obywatele, a nie zrzeszające ich organizacje, mają głos decydujący.

Dialog obywatelski jest także postrzegany w kategorii partycypacji społecznej, gdzie znajduje swoje odbicie w procesach konsultacji społecznych (Chrzanowski, Rościszewska, 2015). Zgodnie z podejściem zaproponowanym przez Sh. Arnstein (2012) można wskazać kilka poziomów partycypacji, różnicując je ze względu na rolę, jaką odgrywają obywatele w tym procesie i wpływ, jaki uzyskują oni na wynik procesu politycznego. Zgodnie z propozycją autorki, wśród form partycypacji znajdują się informowanie oraz konsultacje. Nieco inaczej, ale także z uwzględnieniem roli informowania i konsultacji, prezentuje się koncepcja zakresu partycypacji społecznej jako pochodnej zaangażowania obywatelskiego aranżowanego przez władzę (Zybała, 2011/2012). Podstawowymi jego przejawami są właśnie informowanie i konsultacje, i choć nie gwarantują one obywatelom rzeczywistego wpływu na decyzję polityczną, to jednak ich stosowanie przez władzę jest wyrazem uszanowania prawa obywateli do bycia informowanymi i wysłuchanymi. Wydaje się, że właśnie w tym kontekście właściwe jest wskazanie mediów społecznościowych jako form, które umożliwiają szerokie, bezpośrednie informowanie obywateli, a także zasięganie ich opinii.

Pojęcie „polityki publiczne” A. Zybała (2012) definiuje jako „zracjonalizowane działania i programy publiczne, które oparte są na zgromadzonej, względnie zobiektywizowanej wiedzy i usystematyzowanym procesie projektowania i wykonywania tych działań”. Procesy te są kolejno projektowane i formułowane, wdrażane, a w końcu ewaluowane. W zasadzie na każdym z etapów jest przestrzeń do wykorzystania mechanizmów dialogu obywatelskiego - największa na etapie formułowania polityki publicznej. Angażowanie obywateli zwiększa szanse na uwzględnienie stanowisk interesariuszy i zmniejsza ryzyko protestów, niezadowolenia społecznego będącego skutkiem implementowanych polityk, jednocześnie zwiększa szanse na uzyskanie pozytywnej informacji zwrotnej ze strony obywateli już na etapie ewaluacji. 


\section{Dialog obywatelski na Twitterze - metodologia badania}

Powyższe rozważania doprowadziły do zadania pytania, czy i jak władza wykorzystuje to narzędzie komunikacji do dialogu obywatelskiego. Próba udzielenia na nie odpowiedzi sprowokowała do przeprowadzenia badania i analizy charakteru komunikacji prowadzonej przez wybrane polskie miasta w serwisie społecznościowym Twitter. $\mathrm{W}$ ich toku postawiono następujące pytania badawcze:

Q1 - Czy istnieją dające się opisać style komunikacji polskich miast na Twitterze? Q2 - Czy i w jakim stopniu największe polskie miasta wykorzystują potencjał mediów społecznościowych do prowadzenia dialogu obywatelskiego?

Q3 - Które funkcjonalności i praktyki komunikowania na Twitterze przez podmioty administracji samorządu terytorialnego $\mathrm{w}$ ramach dialogu obywatelskiego online mają potencjał wspierania procesów planowania, implementacji i wdrażania polityk publicznych?

Warto w tym miejscu wskazać przyczyny, dla których zdecydowano się skoncentrować badanie na jednostkach samorządu terytorialnego, a konkretnie miastach, oraz analizować ich komunikację prowadzoną właśnie w serwisie Twitter. Obie te decyzje mają oczywiście charakter ograniczający i utrudniający ekstrapolowanie uzyskanych wyników na wszystkie podmioty administracji publicznej i pozostałe dostępne media społecznościowe. Wybór miast jako podmiotów badania podyktowany był jednak dwiema przesłankami - chcąc badać podmioty administracji publicznej, świadomie zrezygnowano z instytucji administracji rządowej, wychodząc z założenia, że ich polityczna homogeniczność może powodować, iż sposoby wykorzystania Twittera będą podobne. Na tym tle miasta zarządzane przez różne formacje polityczne, w których prezydenci wywodzą się zarówno z ogólnopolskich ugrupowań politycznych, jak i lokalnych komitetów wyborczych, dawały szanse na większe zróżnicowanie sposobów, form i intensywności korzystania z Twittera, co z kolei pozwoliłoby na wyodrębnienie różnych stylów komunikacji i prowadzenia dialogu społecznego. Drugą przesłanką do wyboru dużych miast była struktura użytkowników Twittera, których większa część mieszka właśnie w miastach (wirtualnemedia.pl, 2019). Dodatkowo należy zwrócić uwagę, że badanie rozpoczęło się przed kampanią wyborczą do samorządu terytorialnego w 2018 roku, a dwa kolejne pomiary zostały przeprowadzone po zaprzysiężeniu nowych władz oraz w przybliżeniu po upływie symbolicznych pierwszych stu dni sprawowania urzędów przez nowo wybranych prezydentów.

Z kolei wybór Twittera związany był z jego charakterem w polskim systemie komunikacji politycznej, a także specyfiką samego serwisu - platforma ta umożliwia dynamiczną wymianę informacji i opinii pomiędzy wszystkimi jej użytkownikami, 
a w Polsce stała się ważnym medium politycznym, w którym prowadzone są debaty pomiędzy aktorami politycznymi a społeczeństwem. Twitter jest aktywnie wykorzystywany w różnych funkcjach komunikacji politycznej przez polityków, partie polityczne, instytucje administracji publicznej, organizacje pozarządowe, ale też traktowany jest przez obywateli jako kanał pozwalający na nawiązanie bezpośredniego kontaktu z aktorem politycznym (Annusewicz, Biskup, 2014; Annusewicz, 2015). Zawężenie badania do jednego tylko medium społecznościowego wynika ze specyfiki tegoż, jednocześnie zaproponowana metodologia badania (po odpowiednich modyfikacjach dostosowujących ją do wybranego medium) może pomagać w analizie „dialogowego” potencjału innych mediów społecznościowych, takich jak Facebook czy Instagram, i poszukiwania kolejnych form prowadzenia bezpośredniego dialogu obywatelskiego.

Punktem wyjścia do zaprojektowania badania było założenie, że dialogowy charakter wykorzystania Twittera przez politycznego nadawcę może być opisany za pomocą takich elementów, jak:

- stosunek liczby użytkowników obserwowanych przez konto należące do miasta do liczby użytkowników je obserwujących. Proporcja ta może być bowiem wskaźnikiem intencji komunikowania jednokierunkowego (informowanie) albo dwukierunkowego (konsultowanie, poszukiwanie i analizowanie opinii innych użytkowników). Niewielka grupa obserwowanych może świadczyć o nastawieniu nadawcy do wykorzystania Twittera bardziej jako narzędzia służącego do informowania obywateli,

- charakterystyka obserwowanych - czy w gronie obserwowanych kont znajdują się te należące do instytucji samorządowych, innych miast, mediów, organizacji pozarządowych, czy także do indywidualnych użytkowników - mieszkańców i odwiedzających miasto,

- interakcje z innymi użytkownikami, czyli zakres, w jakim władza wykorzystuje dwukierunkowy potencjał komunikacyjny mediów społecznościowych. Pogłębienie analizy polegało na określeniu, czy ewentualne interakcje miały charakter reaktywny (czyli były odpowiedziami na tweety innych użytkowników, w których np. wymieniono nazwę miasta), czy proaktywny (czyli inicjowały interakcje z użytkownikami, np. poprzez zadawanie pytań, włączanie się w dyskusje prowadzone przez innych użytkowników),

- charakter użytkowników, z którymi podmiot wchodzi w interakcje - czy znajdowali się wśród nich indywidualni użytkownicy?,

- charakter tweetów publikowanych przez użytkownika konta - informujące (czyli zawierające przesłania o charakterze informacyjnym - np. zawierające informacje o aktywności prezydenta miasta, urzędu i podległych mu jednostek), o charakterze promocyjnym (np. łącza do publikacji medialnych, których bohaterem było 
miasto albo prezydent), edukacyjnym (np. $z$ informacjami o nowych regulacjach czy ostrzeżeniach dot. zagrożenia bezpieczeństwa, utrudnień w ruchu) lub angażującym (zawierające pytania, zaproszenia do wyrażenia opinii, łącza do ankiet i sond, zachęcające do działania, podejmowania aktywności),

- udostępnianie przez miasto tweetów publikowanych przez innych użytkowników z uwzględnieniem ich rodzaju (użytkownicy powiązani z miastem - np. podległe instytucje, lokalni politycy, media; inne miasta lub organizacje miast/gmin o charakterze regionalnym, ogólnopolskim lub międzynarodowym; indywidualni użytkownicy - np. mieszkańcy, turyści),

- tzw. polubienia - czyli oznaczanie przez miasto tweetów innych użytkowników jako lubianych. $Z$ uwzględnieniem rodzaju ich autorów (użytkownicy powiązani z miastem - np. podległe instytucje, lokalni politycy, media; inne miasta lub organizacje miast/gmin o charakterze regionalnym, ogólnopolskim lub międzynarodowym; indywidualni użytkownicy - np. mieszkańcy, turyści).

Przeprowadzenie badania polegało na ilościowej weryfikacji liczby obserwujących i obserwowanych, a także liczby udostępnień i polubień tweetów innych użytkowników oraz jakościowej analizie prowadzonych przez konto interakcji, charakterystyki obserwowanych, rodzaju interakcji, charakterystyki publikowanych tweetów, a także charakterystyki użytkowników, z którymi miasto wchodziło w interakcje, których tweety były udostępniane i oznaczane jako polubione.

Pomiar i analizy były przeprowadzone trzykrotnie:

- po raz pierwszy 17 maja 2018 r. (analizie jakościowej poddano aktywność użytkowników na przestrzeni trzech miesięcy poprzedzających pomiar),

- po raz drugi 11 grudnia 2018 r. (analizie jakościowej poddano aktywność użytkowników na przestrzeni od pierwszego pomiaru),

- po raz trzeci 26 marca 2019 r. (analizie jakościowej poddano aktywność użytkowników na przestrzeni od drugiego pomiaru).

Analizie poddano oficjalne konta prowadzone przez siedem miast wojewódzkich²:

- Kraków (@Krakow_PL),

- Katowice (@Umkatowice),

- Poznań (@Cityofpoznan),

- Lublin (@Miasto_lublin),

- Rzeszów (@RZeszow),

- Warszawa (@Warszawa),

- Gdańsk (@Gdansk).

2 W nawiasach podano nazwy użytkowników kont prowadzonych przez badane miasta na Twitterze. 
Należy zwrócić uwagę na ograniczenia przeprowadzonego badania - w toku analiz nie brano pod uwagę jakości (tematyki treści, języka czy wykorzystania multimedialnych form komunikacji) publikowanych, udostępnianych i oznaczanych jako polubienie tweetów. Jedynym jakościowym elementem analizy tweetów był ich potencjalnie angażujący lub informacyjny charakter. Podobnie nie analizowano treści interakcji, czasu reakcji użytkownika na tweet, w którym został wymieniony, nie analizowano też liczby i częstotliwości publikowania tweetów. Mimo że kwestie te przedstawiają się nad wyraz interesująco, są raczej elementami wpływającymi na wizerunek nadawcy (Annusewicz, 2017), a ponieważ badanie koncentrowało się na aspekcie dialogowym, zostały one pominięte.

\section{Trzy style dialogu obywatelskiego na Twitterze}

$\mathrm{W}$ toku prowadzonych pomiarów i analiz udało się zdefiniować trzy charakterystyczne, różniące się style prowadzenia dialogu obywatelskiego w mediach społecznościowych, które zostały nazwane w sposób metaforyczny, z podkreśleniem ich najważniejszych cech:

- „słup ogłoszeniowy”,

- „infolinia”,

- „klub dyskusyjny”.

\section{„Słup ogłoszeniowy”}

Jest to najmniej partycypacyjna forma prowadzenia dialogu obywatelskiego na Twitterze. Charakteryzuje się skoncentrowaniem na realizacji funkcji informacyjnej prowadzonej komunikacji i realizowana jest $\mathrm{w}$ formule komunikacji jednokierunkowej, nastawionej na nadawanie i niezainteresowanej informacjami zwrotnymi. Cechami charakterystycznymi tego stylu są:

- niewielka (mniejsza od 100) liczba obserwowanych kont innych użytkowników, wśród których ostatecznie dominują instytucje samorządowe, lokalni politycy, inne jednostki samorządu terytorialnego i podmioty administracji publicznej,

- brak jakichkolwiek interakcji z innymi użytkownikami,

- udostępnianie i dodawanie do polubionych tweetów wyłącznie innych podmiotów samorządowych, ewentualnie przedstawicieli mediów,

- publikacja tweetów o wyłącznie informacyjnym charakterze.

Spośród badanych miast dwa - Kraków oraz Katowice - w ten właśnie, informacyjny, ograniczenie partycypacyjny sposób korzystało z Twittera jako narzędzia 
do prowadzenia dialogu obywatelskiego. Co ciekawe, styl ten nie zmieniał się w poszczególnych badanych okresach. W okresie od maja $2018 \mathrm{r}$. do marca $2019 \mathrm{r}$. liczba obserwowanych użytkowników przez konto Krakowa wzrosła z 85 do 92 (pomiędzy grudniem 2018 r. a marcem 2019 r. wzrost o jednego użytkownika), zaś Katowic z 14 do 15. Dodajmy, że wśród obserwowanych dominują lokalni politycy, dziennikarze, przedstawiciele lokalnych elit, a także konta instytucji. W badanym okresie nie pojawiały się także interakcje pomiędzy kontami obu miast a innymi użytkownikami medium społecznościowego. Zarówno konta Krakowa, jak i Katowic udostępniały wpisy wyłącznie podległych sobie instytucji, lokalnych liderów politycznych i dziennikarzy. Polubienia w przypadku Krakowa miały wprawdzie charakter sporadyczny (z 1117 ich liczba w okresie badania wzrosła do 1533, a następnie do 1841), jednak warto podkreślić, że dotyczyły one nie tylko wpisów opublikowanych przez podległe miastu instytucje czy lokalne elity, ale także inne organizacje i instytucje samorządowe, a często także przez indywidualnych użytkowników - turystów i mieszkańców. W przypadku Katowic ten element wydaje się jednak niewykorzystany - łącznie jako polubione przez konto tego miasta oznaczono 13 postów, zbyt mało, by wnioskować cokolwiek o ich jakości.

Wydaje się, że zarówno Kraków, jak i Katowice korzystając z Twittera, czynią to w innych celach niż prowadzenie dialogu obywatelskiego i unikają komunikacji dwukierunkowej czy angażowania się w budowanie relacji z użytkownikami serwisu.

\section{"Infolinia"}

Z przeprowadzonych analiz wynika, że jest to najczęstszy styl prowadzenia dialogu obywatelskiego na Twitterze. Charakteryzuje się on:

- stosunkowo dużą liczbą obserwowanych kont (między 100 a 400), choć wśród obserwowanych poza podległymi miastu instytucjami znajdują się głównie lokalni dziennikarze, aktywiści, politycy opozycyjni,

- reaktywnymi interakcjami, odpowiadaniem na tweety, które wymieniają wprost nazwę użytkownika (tzw. mention),

- udostępnianiem i dodawaniem do polubionych tweetów także indywidualnych użytkowników serwisu, w szczególności tych, które są odpowiedziami na tweet miasta oraz tych, w których treści pojawia nazwa (mention) miasta,

- publikacją tweetów w większości o charakterze informacyjnym.

Z badanych miast styl „infolinia” reprezentują Poznań i Warszawa. Lublin oraz Rzeszów także zostały włączone do tej grupy, bo choć nie spełniają wszystkich powyższych kryteriów (niska liczba obserwowanych), to jednak ich charakter komunikacji z innymi użytkownikami ma dużo bardziej partycypacyjny i relacyjny charakter niż 
w przypadku Krakowa czy Katowic. I tak zarówno Warszawa, jak i Poznań obserwują powyżej 100 innych użytkowników, przy czym w przypadku Warszawy liczba ta w okresie badania wzrosła ze 164 do 169 (środkowy pomiar wskazał $167^{3}$ ), a spadła dla Poznania z 271 do 268 (środkowy pomiar wskazał 269). Wśród obserwowanych przez warszawskie konto użytkowników znajdują się przedstawiciele korpusu dyplomatycznego, lokalni politycy i urzędnicy, osoby publiczne (np. sportowcy pochodzący z Warszawy), warszawskie dzielnice oraz instytucje samorządowe, lokalni dziennikarze, inne polskie miasta - w zasadzie w tej grupie nie ma przeciętnych, indywidualnych użytkowników, którzy w jakiś wyraźny sposób nie byliby związani z miastem. Podobnie rzecz przedstawia się w przypadku Poznania, tu jednak warto zaznaczyć, że wśród obserwowanych sporadycznie pojawiają się indywidualni użytkownicy serwisu. Konto Lublina miało w okresie badania w gronie obserwowanych początkowo 62, następnie 63, w końcu 80 użytkowników - w większości lokalnych polityków, instytucje, media, uczelnie wyższe, a także inne polskie miasta. Z kolei Rzeszów do grona obserwowanych dodał wyłącznie cztery konta należące do dwóch zagranicznych miast (Nowy Jork i Amsterdam), australijskiego stanu Queensland oraz zagranicznej organizacji o charakterze ekologicznym, miasto zatem nie obserwuje nikogo, z kim mogłoby potencjalnie podjąć dwukierunkowy dialog obywatelski.

Spośród tej grupy miast jedynie Lublin wchodził w interakcje z innymi użytkownikami serwisu, lecz miały one przede wszystkim charakter reaktywny.

O zaliczeniu wspomnianych czterech miast do grupy reprezentującej styl nazwany metaforycznie „infolinią? zadecydowało przede wszystkim stosunkowo częste (szczególnie w przypadku Warszawy i w trochę mniejszym stopniu Poznania) udostępnianie nie swoich tweetów oraz oznaczanie jako polubione. Zebrane dane (w szczególności dotyczy to liczby polubień ${ }^{4}$ - tabela 1) pokazują, że - wprawdzie z różnym natężeniem - każde z tych miast dostrzegało komunikację publikowaną przez innych użytkowników i reagowało na nią polubieniem lub udostępnieniem.

Autorami udostępnianych i dodawanych do polubionych wpisów byli często indywidualni użytkownicy Twittera - warto podkreślić w tej grupie miast Rzeszów, który chętnie zarówno udostępniał, jak i dodawał do polubionych tweety zwykłych mieszkańców czy osób z Polski i zagranicy, które odwiedziły miasto.

3 Jako ciekawostkę można podać fakt, że dwa konta dodane do obserwowanych przez Warszawę między drugim a trzecim pomiarem, a zatem już po zaprzysiężeniu prezydenta Rafała Trzaskowskiego, należą do niego samego oraz do wyłonionego krótko po wyborach nowego rzecznika prasowego Urzędu Miasta Stołecznego Warszawy.

4 Serwis Twitter nie udostępnia danych liczbowych pozwalających na określenie liczby udostępnionych postów - można wprawdzie uzyskać informację, ile razy dany post był udostępniony, ale nie ma danych dotyczących liczby udostępnień przez poszczególnych użytkowników. 
Spośród omawianych w tej części miast jedynie Warszawa i Poznań sporadycznie publikowały wpisy o charakterze angażującym - były to zaproszenia do wzięcia udziału w ankietach, zaproszenia do nadsyłania zdjęć przedstawiających miasto. Dominująca część publikacji miała charakter informacyjny.

Tabela 1. Liczba polubień tweetów innych użytkowników przez konta badanych miast

\begin{tabular}{|l|c|c|c|}
\hline Miasto & $\begin{array}{c}\text { Liczba polubień podczas } \\
\text { pierwszego pomiaru } \\
17 \text { maja 2018 r. }\end{array}$ & $\begin{array}{c}\text { Liczba polubień podczas } \\
\text { drugiego pomiaru } \\
11 \text { grudnia 2018 r. }\end{array}$ & $\begin{array}{c}\text { Liczba polubień podczas } \\
\text { trzeciego pomiaru } \\
\text { 26 marca 2019 r. }\end{array}$ \\
\hline @Warszawa & 6639 & 8861 & 9627 \\
\hline @CityofPoznan & 4462 & 4472 & 4477 \\
\hline @Rzeszow & 367 & 423 & 484 \\
\hline @Miasto_Lublin & 245 & 249 & 341 \\
\hline
\end{tabular}

Źródło: opracowanie własne.

\section{„Klub dyskusyjny"}

Ostatni ze stylów komunikacji - najbardziej intensywny i w największym stopniu pozwalający na nazwanie go partycypacyjnym w rozumieniu istoty dialogu obywatelskiego - to format nazwany metaforycznie „klubem dyskusyjnym”. Charakteryzuje się on:

- dużą liczbą obserwowanych kont (powyżej 400), wśród których istotną grupę stanowią mieszkańcy, osoby podające identyfikację z miastem/gminą - np. w opisie profilu wskazujące nazwę miejscowości,

- interakcjami proaktywnymi (również reaktywnymi) polegającymi na włączaniu się w toczone na Twitterze dyskusje nie tylko wtedy, kiedy w jakiś sposób dotyczą one miasta, ale także gdy wykraczają poza tematykę danej miejscowości,

- dużą liczbą polubień i udostępnień wpisów autorstwa indywidualnych, nieznanych szerzej użytkowników Twittera,

- angażującą treścią publikowanych tweetów,

- reakcjami na tweety, w których nie pojawia się mention użytkownika.

Spełnienie wyżej wymienionych warunków oznacza, że podmiot korzystający z mediów społecznościowych nie tylko w pełni wykorzystuje ich potencjał informacyjny, ale także korzysta $\mathrm{z}$ możliwości konsultacyjnych oraz budowania relacji z obywatelami, które mogą przełożyć się na zwiększenie zaufania do administracji samorządowej i podnieść jakość dialogu obywatelskiego prowadzonego w świecie realnym - offline. Spośród badanych miast jedynie Gdańsk (@Gdansk) spełnił wszystkie powyższe kryteria (za wyjątkiem udostępniania postów autorstwa indywidualnych 
użytkowników). Miasto to zdecydowanie wyróżnia się liczbą obserwowanych użytkowników, warto jednocześnie zaznaczyć, że wzrasta ona systematycznie: w maju 2018 r. wynosiła 956 kont, w grudniu 2018 r. - 1015, a w marcu 2019 r. - 1076. Imponująco przedstawia się także liczba tweetów polubionych przez konto @Gdansk - w maju 2018 r. zbiór ten stanowiło ok. 60800 kont ${ }^{5}$, w grudniu 2018 r. - ok. 64 400, zaś w marcu 2019 r. - ok. 67 900. Powyższe dwa parametry ilościowe jasno pokazują, że możliwe jest angażowanie się jednostki samorządu terytorialnego w budowanie relacji z użytkownikami Twittera. Deliberatywne nastawienie Gdańska możemy także zaobserwować w łatwym wchodzeniu w interakcje - zarówno reaktywne, jak i proaktywne. Z konta użytkownika udzielane są odpowiedzi mieszkańcom, którzy wypowiedzieli się na temat tweetu opublikowanego wcześniej przez miasto, komentowane są tweety, w których autor wymienił mention Gdańska. Co ważne i wyjątkowe wśród badanych miast, @Gdansk wchodził też w interakcje z użytkownikami, którzy w swoich wpisach nie oznaczyli miasta w sposób charakterystyczny dla Twittera - poprzez mention (np. @gdansk) lub hasztag (\#gdansk). Oznacza to prawdopodobnie, że miasto prowadzi aktywny monitoring mediów społecznościowych pozwalający z jednej strony na szybkie zareagowanie w przypadku pojawienia się krytyki czy oskarżeń pod adresem urzędu miasta, ale też - niejako przy okazji - na proaktywne nawiązywanie relacji z użytkownikami serwisu. Te wzmacniane są także pojawiającymi się tweetami o charakterze angażującym - nie tylko zaproszeniami do udziału w konkursach czy zachęcaniem do różnego rodzaju aktywności poza Twitterem (np. do udziału w wolontariacie, zapoznania się z zasadami korzystania z usług oferowanych przez miasto czy zgłaszania pomysłów na nazwy miejskich instytucji), ale też wpisami angażującymi użytkowników serwisu do aktywności pod postem miasta. Mowa tu o postach zawierających ankiety czy pytania skierowane wprost do innych użytkowników.

$* * *$

Wyniki analiz pozwalają na sformułowanie odpowiedzi na zadane pytania badawcze. Odpowiedź na pierwsze pytanie (Czy istnieją dające się opisać style komunikacji polskich miast na Twitterze?) jest twierdząca - analiza nawet niewielkiej liczby profili twitterowych wybranych miast pokazuje powtarzalne schematy komunikacyjne, także w kontekście wykorzystania tego serwisu do prowadzenia dialogu obywatelskiego. Trzy opisane wyżej i metaforycznie nazwane style: „słup ogłoszeniowy”, „infolinia” i „klub dyskusyjny” są próbą wskazania podobieństw w obecności polskich miast $\mathrm{w}$ tym medium społecznościowym. Zaproponowane kryteria nie są jednak ostre,

\footnotetext{
5 W przypadku dużych liczb serwis Twitter podaje wartości zaokrąglone.
} 
celowo stosowano je raczej opisowo niż jako „twarde”, interpretowane zerojedynkowo wskaźniki. Wynika to przede wszystkim z faktu, że komunikacja w mediach społecznościowych pozwala na realizację wielu celów, ma co najmniej kilka funkcji - za jej pomocą właściciele kont informują o swoich działaniach (funkcja informacyjna), zachęcają do określonych aktywności (funkcja promocyjno-perswazyjna), uczą i starają się wpływać na zachowania społeczne (funkcja edukacyjna), starają się kreować wydarzenia, które znajdą swoją relację w innych, w tym tradycyjnych, mediach (funkcja agenda-setting), prowadzą zbiórki pieniędzy (funkcja ekonomiczna), wreszcie próbują nawiązać dialog z odbiorcami (funkcja dwukierunkowego komunikowania) (Annusewicz, 2009).

Powyższa konstatacja prowadzi nas do próby odpowiedzenia na drugie pytanie - Czy i w jakim stopniu największe polskie miasta wykorzystują potencjał mediów społecznościowych do prowadzenia dialogu obywatelskiego? Przeprowadzone badania wskazują jasno, że - szczególnie w przypadku badanego Twittera - miasta mogą aktywniej prowadzić dialog obywatelski online poprzez media społecznościowe. Wydaje się, że potencjał, który daje dwukierunkowość komunikacji, jest nie w pełni wykorzystany - spośród siedmiu badanych miast tylko jedno (Gdańsk) spełniało przytłaczającą większość kryteriów pozwalających uznać, że aktywnie dyskutuje, prowadzi dialog z mieszkańcami będącymi użytkownikami Twittera.

Tworząc metodologię badania, czyli badając serwis społecznościowy Twitter, jego funkcjonalności i praktykę wykorzystania przez podmioty samorządu terytorialnego - szukając odpowiedzi na trzecie pytanie badawcze - wyodrębniono aspekty, w których dialog obywatelski online, prowadzony w mediach społecznościowych, może wspierać procesy planowania, implementacji i ewaluacji polityki publicznej. W sferze jej planowania oraz ewaluacji największy potencjał mają opisane wyżej tweety angażujące. Urzędnicy odpowiedzialni za planowanie polityki publicznej mogą kierować do użytkowników serwisów społecznościowych pytania otwarte i zamknięte, dotyczące zarówno ich potrzeb, jak i opinii. Ze względu na duży potencjalny zasięg wpisów w mediach społecznościowych mogą też one służyć jako narzędzie promocji tradycyjnych form konsultacyjnych. W kontekście fazy implementacji informacji będą dostarczać w głównej mierze reakcje użytkowników na komunikację proaktywną prowadzoną przez miejskie czy gminne konto - nawet, jeśli nie ma ona charakteru angażującego tylko informacyjny, to zarówno reakcje w postaci polubień i udostępnień, jak i komentarze odbiorców pod tweetami nadawcy mogą być źródłem cennych informacji, $w$ tym przydatnych do zarządzania ryzykiem w procesach realizacji polityki publicznej.

Należy oczywiście zaznaczyć, że przeprowadzone badanie miało charakter cząstkowy i trudno wyprowadzać generalne wnioski dotyczące prowadzenia dialogu 
obywatelskiego przez wszystkie polskie miasta we wszystkich dostępnych mediach społecznościowych. Celem autora było jednak wskazanie „dialogowego” potencjału mediów społecznościowych, a także zachęcenie kolejnych badaczy do eksplorowania innych kanałów komunikacji w Internecie, w tym przede wszystkim mediów społecznościowych, takich jak Facebook czy Instagram, i poszukiwania kolejnych form prowadzenia bezpośredniego dialogu obywatelskiego. Jednocześnie można zdecydowanie wskazać, że media społecznościowe mają istotny potencjał komunikacyjny, który może być wykorzystywany przy zarządzaniu polityką publiczną i tym samym wpływać na jej jakość. Wydaje się, że najbardziej angażujący, partycypacyjny model „klubu dyskusyjnego" daje największy potencjalny wpływ na kształt i tym samym jakość komunikowanej dialogowo polityki publicznej. Wynika to oczywiście z faktu większego zaangażowania interesariuszy, którzy na każdym etapie procesu zarządzania mogą się czuć angażowani i potrzebni, co w ostatecznym rozrachunku może zmniejszać ryzyko społecznego niezadowolenia z prowadzonej polityki publicznej. Jednak nawet najmniej „dialogowy” model „infolinii” cechujący się najniższym poziomem partycypacji może pozytywnie wpłynąć na komunikację polityki publicznej poprzez poszerzenie grupy docelowej o niezorganizowanych obywateli. Zagadnienie to także może być przedmiotem dalszych analiz.

\section{Bibliografia}

Annusewicz, O. (2009), Funkcje komunikowania politycznego w Internecie, w: Zaleśny, J., Annusewicz, O. (red.) (2015). Media społecznościowe w kampaniach wyborczych 2015. e-Politikon, 16.

Annusewicz, O. (2017). Twitter jako przestrzeń autoprezentacji politycznej. Zarządzanie wizerunkiem polityka w mediach społecznościowych, w: Annusewicz, O. (red.), Zarządzanie wizerunkiem w polityce, Studia Politologiczne, 45.

Annusewicz, O., Biskup, B. (red.) (2014). Political Communication on the Internet. e-Politikon, 9.

Arnstein, Sh.R. (2012). Drabina partycypacji, w: Erbel, J., Sadura, P. (red.), Partycypacja. Przewodnik Krytyki Politycznej.

Błuszkowski, J. (red.) (2009), Rozumienia polityki. Studia Politologiczne, 14.

Bogacz-Wojtanowska, E., Hess, A., Lisowska-Magdziarz, M., Lendzion, M., Nowak, K. (2017). Dialog obywatelski w Krakowie w opiniach mieszkańców, przedstawicieli organizacji pozarządowych i mediów. Nowy Targ-Kraków.

Chrzanowski, O., Rościszewska, E. (2015). Konsultacje okietznane, https://partycypacjaobywatelska.pl/wp-content/uploads/2015/12/1_konsultacje_okielznane.pdf (dostęp 28.03.2019).

Cisek-Lachowicz, M., Kichewko, K. (2018). Dialog obywatelski w praktyce. Central European Journal Of Social Sciences And Humanities, 2(18). 
Rymsza, M. (2007). O polityce państwa wobec trzeciego sektora i instytucjonalizacji dialogu obywatelskiego, w: Rymsza, M. (red.), Organizacje pozarządowe. Dialog obywatelski. Polityka państwa. Warszawa.

Zybała, A. (2011/2012). Poziomy partycypacji obywatelskiej. Trzeci Sektor, numer specjalny. Zybała, A. (2012). Polityki publiczne. Doświadczenia w tworzeniu i wykonywaniu programów publicznych $w$ Polsce i $w$ innych krajach. Warszawa.

\section{Źródła internetowe:}

Wirtualnemedia.pl, Wśród polskich użytkowników Twittera przeważają mężczyźni, osobyz dużych miast i ze średnim lub wyższym wykształceniem, https://www.wirtualnemedia.pl/artykul/ twitter-jacy-sa-jego-polscy-uzytkownicy-przewazaja-mezczyzni-osoby-z-duzych-miast-i-ze-srednim-lub-wyzszym-wyksztalceniem-analiza (dostęp 28.03.2019). 